\section{Breakfast, attachment styles and health of female university students}

Pervaiz, Zoya $\measuredangle$

Lahore College for Women University, Lahore, Pakistan (zoyapervaiz_lcwu@hotmail.com)

Sohail, Talat

Lahore College for Women University, Lahore, Pakistan (talat_lcwu@yahoo.com)

Received: 19 January 2014 Available Online: 3 April 2014

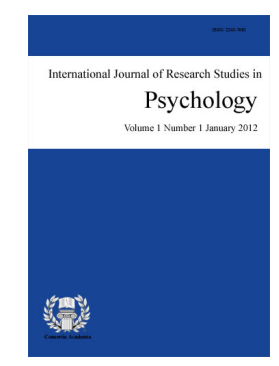

ISSN: $2243-7681$ Online ISSN: 2243-769X

OPEN ACCESS

\title{
Abstract
}

The present research was carried out on the relationship between breakfast, attachment patterns and health of university students. Correlation research method was used in the study. Purposive sampling was used to collect the sample. Purpose of the study was to explore the link between the breakfast, attachment pattern and health of university students. A sample of 200 university students was selected for the research. Instruments used were Adult Nutrition and Performance Questionnaire, Relationship Questionnaire and General Health Questionnaire. Independent sample chi square was used to explore the relationship between breakfast and health outcome. It was concluded that university student who daily had their breakfast, had better health than those who had irregularity or they omitted breakfast. Analysis of variance was applied to determine the health among three models of attachment. Health among the three attachment styles was slightly insignificant.

Keywords: breakfast; attachment styles; health; self-model; others-model; both-model 


\section{Breakfast, attachment styles and health of female university students}

\section{Introduction}

The current study titled as Breakfast, attachment styles and general health of female university students is focusing on the breakfast taking habits of students and general health of university students and considering university student's attachment styles. Previously researches have been conducted on the relationship between breakfast and academic performance. Breakfast is the most important meal of the day which is taken early in the morning when an individual gets up after night sleep of 10-12 hours when individual's stomach remains empty and hunger slows down their performance in daily tasks so the body needs fuel to work better. If the body is not refueled through food, body may not work better and is unable to perform the daily tasks (Ozcelik, Ozdogan, \& Surucuoglu, 2010).

Cueto (2001) said that if individual does not take breakfast then it will be difficult for the individual to perform daily tasks. Consuming breakfast regularly helps people to maintain their glucose level and perform daily tasks regularly. People who skip breakfast consume low amount of protein and calories than those people who have their breakfast regularly (Zabik, 1987). People who skip breakfast consume food high in calories throughout the day. Breakfast consumption is the leading factor in the maintenance of nutrition (Morgan, Stampley, \& Zabik, 1986). Studies have proved that taking breakfast is helpful to perform better in academic tasks and this phenomenon has drawn attention of many researchers (Mathew \& Pollitt, 1998). Those who skip breakfast experience starvation of food. Food starvation is harmful for maintaining good health and performing in daily activities (Alaimo, Briefel, Frongillo, Olson, 1998, 2001a, 2001b).

According to the nonprofit organization Food Research and Action Center, students who skip breakfast have poor learning ability. Those with empty stomach may not work properly (Murphy, 2007). Students who skip breakfast show cognitive, behavioral, emotional, academic and visual problems. They show absenteeism, hyperactivness, attention and concentration problems and tardiness. Sometimes they seek special education, counseling and repeating the same class many times (Jellinek et al., 1998). They show difficulty in differencing the similar objects (Cueto, Jacob \& Pollitt, 1998; Greenfiled, Liebel \& Pollitt, 1981). They get lower grades in the subjects like Mathematics and English. They often get suspended from school (Alaimo et al., 2001a). They have poor performance on cognitive tasks given to them in classroom (Grantham \& Simeon, 1989; Pollitt, 1995).

According to the Food Research and Action Center, students who eat healthy and complete breakfast perform better on academic tasks if compared with those students who take unhealthy, irregular breakfast or the students who take no breakfast at all (Murphy, 2007). Less mistakes and higher grades have been reported from the students who eat regular breakfast (Abrahamsson, Fletcher, Jartelieus, \& Wyon, 1997). According to Akivis, Vaisman, Vakil, and Voet (1996) that students who take breakfast right before the test or lecture have better performance on academic task than those students who have regular breakfast but take at home. Students who eat breakfast at school have better concentration, attention and memory abilities (Bryant, Courtney, McDermott, \& Morris, 2010; Chandler, Connolly, Grantham, \& Walker, 1995; Chang, Grantham, \& Walker, 1998; Hails, Helms, Pincock, Richardson, \& Wesnes, 2003).

Some schools offers free breakfast program and students who participates in such programs have higher scores on the subjects like Mathematics and English, better behavior like improve regularity and decrease tardiness, depression and anxiety. School breakfast program is very beneficial for the students and the students who participate in such programs have better performance in academic tasks than those who do not participates in school breakfast program (Chang et al., 1998; Kane et al., 1998). Students who join breakfast program are more likely to have healthy breakfast rich in vitamins (Bhattacharya, Currie, \& Haider, 2006; Clark \& Fox, 2009; Gleason \& Suitor, 2001). Students who join healthy and nutritional breakfast programs feel less hunger (Green et 
Breakfast, attachment styles and health of female university students

al., 2002). Providing a nutritional breakfast in school is beneficial for students who have low income and cannot eat healthy breakfast (Ahn \& Bartfeld, 2011).

\subsection{Attachment Theories}

Attachment theory was collectively introduced by John Bowlby and Mary Ainsworth (Ainsworh \& Bowlby, 1991). Bowlby created the primary assumptions in the ideology of attachment theory. Through the progressive approach of Ainsworth the concepts of Bowlby were even not checked it also spread out the theory. Bowlby and Ainsworth did their jobs separately but they were inspired by the psychoanalysis approach of psychology (Bretherton, 1992).

In the 1948, Bowlby was studying the children who were not living with their parents but they were either admitted in hospitals or stayed in organizations instead of living with parents. Bowlby requested Robertson who joined him as a trained viewer who formerly was working in Freud's organization made for unsheltered kids. Freud instructed all the stakeholders of its organization to document the kids overall conduct and then arrange gathering every week for argumentations and debate over documented behaviors of kids (Bretherton, 1992). In 1950's Ainsworth joined Bowlby Company (Emerson \& Schaffer, 1964). Ainsworth started her career as analyst and she was inspired by Robertson documentations of kid's behavior and planned to follow Robertson' approach of naturalistic observation (Bretherton, 1992). After World War two Bowlby got a chance to draft handouts about the well-being of unhoused kids who got separate from their mothers.

Bowlby's attachment theory helps in discovering the dimensions of the connections developed between the child and parents because infants and caregiver association was his center of attention. Bowlby also stated that developmental process continues throughout the life and this declaration provided an opportunity to psychologist working in development area to explore the phenomenon. A research was conducted to explore the individual's deeds, performances, attitude and activities comes from knowledge, skills, familiarity and practice gained from attachment styles. Hazan and Shaver stated that childhood and adulthood relationships remain similar throughout life (Barrett \& Pietromonaco, 2000). Studies were conducted to examine the outcomes of the individual's attachment style what they experience and what they observe after establishing the attachment relationships. Researches mostly examine the nature of the relationship between child and caregiver not to explore the nature of attachment style and added that attachment relationship better to be explored in the adult's attachment style.

Hazan and Shaver stated that sometimes adults have the same attachment pattern as they have in their childhood. Ainsworth, who worked on infants and children, described attachment styles of infant, which can also be used on adults. Studies have been conducted to investigate adult's love relationship (Carnelly, Jaffe, \& Pietromonaco, 1994; Collins \& Read, 1990; Hazan \& Shaver, 1987; Simpson, 1990). Others have conducted the adult's relationship with family and friends (Bartholomew \& Horowitz, 1991). And the next step is to investigate the nature of close and casual relationship (Barrett \& Pietromonaco, 1997; Kirkpatrick \& Shaver, 1992; Mikulincer \& Nachshon, 1991). Hazan and Shaver(1987) presented article primarily to investigate the infant's relationship and then focused on the adult's love relationship and concluded that individual differences exists in individual's attachment styles and each individual has different nature of love from the other one.

Bartholomew and Horowitz said that attachment enhances closeness, love and care in parent-child relationship. Among the all attachment styles secure attachment style is considered the most suitable style for children because through this style children find themselves as secure (Sroufe \& Waters, 1977). On the basis, of strength and nature of the attachment style, child shapes and develops its bond with caregiver. Endurance of the attachment styles is determined by the excellence in the relationship between child and caregiver (Charnov, Estes, Gardner, Lamb, \& Thompson, 1985). Children's early experiences with the attachment figure help him to further develop their associations in later life. An infant cannot express its feelings verbally instead forms a rough sketch of attachment figure in the mind. This concept was called internal working model which was developed by Bowlby. Three types of behaviors have been reported to show by the infants when the infant respond to the 
attachment figure. When the infant get close or nearer to the attachment figure is described as proximity seeking. Once the infant comes close to attachment figure then he finds it frustrate to get separate from caretaker and protests by weeping or crying against separation is called as separation protest. Infant establishes strong relationship with caregiver and starts to investigate and explore the world and the surroundings around the infants (Hazan \& Shaver, 1987; Segrin \& Flora, 2005).

Child represents different types of responses when he got isolate from his caregiver especially mother (Hazan \& Shaver, 1987). Bowlby largely worked on the separation because this is dichotomous if the child is separated or not there is no mid-way. There are three phases of separation protest, despair and detachment (Berghaus, 2011). The first response is protest, child reflects the behaviors like, weeping, look for the caretaker, opposing and rejecting relaxing attempt of people in the surrounding other than the caretaker. The second response is despair, after protesting child shows the sentiment of despair, in this phase child shows unhappiness. Third and final phase is detachment; child shows disconnection from his caretaker. Good attachment style establishes strong relationship between caregiver and children and save them from harm.

Ainsworth introduced the concept of Strange Situation. Infant and mother stayed in a room then a third person enters in the room then after that mother leaves the room then later rejoins them. On the second step mother leaves the room and infant is left alone mother rejoins the infant and accompanied by another person (Bretherton, 1992). It was concluded that child starts crying when mother leave the child and stops crying when mother rejoins the child. This is characterized as secure style. Other children avoid their mother and do not make contact with mother when she rejoins the child called avoidant style. Another group of children show anger and aggression towards mother when she rejoins the child called ambivalent style (Bretherton, 2003).

According to the Bowlby's view strong attachment pattern helps children to be close to their mother because they mostly rely on their mother. During infancy, when the infant is unable to move and walk then infants use different technique like crying, smiling to gain the mother's attention. When infant starts walking and talking, then he moves toward mother to get mother's attention. Mother becomes a source of exploring the surrounding and establishing and maintaining good relationship with other relatives. According to Ainsworth mother who does not quickly respond to the child need leads the child to exhibit the behaviors like anger, aggression and avoidance.

Attachment in adolescents - Adolescence is the time when individual develops its identity (Shaver \& Tracy, 2001). When a child grows up and reaches to its adolescent stage, then he develops new social associations with friends and peers other than the family member, siblings and parents (Holland \& Moretti, 2003). Evolution from childhood to adolescent is accomplished through a strong connection with parents not through the isolation from caretakers or parents (Deci, Grolnick, \& Ryan, 1995; Lamborn \& Steinberg, 1993). Attachment style has similar outcomes in adolescents as it has in childhood and parent's sympathy is very important to carry on the adolescent's secure attachment style (Allen et al., 2003). Those adolescents who have the secure attachment style are not involved in unhealthy activities (Collins, Cooper, \& Shaver, 1998). Adolescents who have secure attachment styles accept the change in schooling from primary to middle and then higher level as compared to those who have anxious, avoidant or fearful attachment styles (Doyle, Ducharme, \& Markiewicz, 2002). Adolescents having these types of attachment style are at higher risk of committing suicide (Lessard \& Moretti, 1998). They are more indulge in substance abuse (Lessard, 1994). Brooks and Paikoff (1991) stated that differences between parent and adolescents start in the stage of adolescence. Differences between parents and adolescents start because sometimes parents want to be incharge of their children (Almeida, Barker, \& Galambos, 2003). To maintain the connection, association and bond between parents and adolescents is the main characteristic of attachment theory (Allen, Kuperminc, \& Moore, 1997). In order to maintain a strong association between parents and adolescents this is necessary to appreciate the other's vision. Children of the parents who love and believe on their children successfully transit to the next stage that is of the adults (Moretti \& Peled, 2004). 
Attachment in adults - Psychologists working in the development specialty started their work on the infant-caregiver relationship but also focused on investigating and disclosing the adult's associations with caregivers (Barrett \& Pietromonaco, 2000). John Bowlby and Mary Ainsworth worked on infants and investigated attachment styles of parents and children (Hazan \& Shaver, 1987). Attachment styles are also important in adulthood as well as in childhood. Researches have been conducted on the endurance of the attachment style. Adult attachment interview is used to explore the nature and quality of attachment style. Through the adult attachment interview, the nature of mother-child relationship is anticipated. Kobak and Sceery (1988) in a study conducted interview and discovered that secure individuals feel comfort and portray caretaker as helpful figures, those with avoidant consider oneself as uncomfortable and caregiver as unhelpful, and those having anxious-resistant sees oneself as uncomfortable and attachment figure as helpful.

Hazan and Shaver introduced the concept of love in adult attachment style. They did not depend on interviews but they focused on how individual perceives themselves. They discovered that those who have insecure attachment style comparatively have adverse and short term relationships than the participants having secure attachment style. They also had inability to establish associations with the attachment figure. Participants with insecure attachment style mostly distrust oneself and have lower ability to admit and recognize the caretaker if compared with those having secure attachment style (Bartholomew \& Horowitz, 1991). Works has been done on love and family associations. Developmental specialty started their work to explore the phenomenon of adult's associations (Barrett \& Pietromonaco, 2000).

Theorists who worked on adult attachment style accepts the fact that attachment style changes across the life span it does not remain stable throughout the individual's life (Berman \& Sperling, 1994; Bretherton, 2003; Hazan \& Shaver, 1990; Pincus, Ray, \& Simonelli, 2004). Bartholomew used Bowlby's mental models to shape the adult's attachment style (Bartholomew, 1990). Four attachment styles have been explained combined with two models the model of self and the model of others. Self model explains that how much worthy, positive and constructive individual feels about oneself as well as expectation from people that surround the person. Other's model tells what individual thinks about other people such as caregiver whether they are approachable to meet the person's needs or not. These two models investigate the degree of self worth and other's accessibility (Bartholomew \& Griffin, 1994).

Four attachment styles are secure, preoccupied, dismissing and fearful. In the secure attachment style individual has positive view of self and others. These adults have high confidence level of self and others. In the dismissing style, adult has positive self and negative others because adult avoid significant other to escape from rejection so they ignore and avoid developing strong relationship with others but they are more confident about themselves as well as independent so they avoid other people. In the preoccupied style individual has negative self and positive others. These adults have less self-esteem so they rely on others but if their needs are not met they experience more pain and the feelings of being rejected. While in the last fearful style adult has negative view of both self and others as they rely on others for the approval of the self and they also have the fear of being neglected by the significant others (Bartholomew \& Griffin, 1994). Evidence shows that two internal working models and four attachment styles are similar to the adult's actual attachment relationship (Hazan \& Shaver, 1993). Some studies conclude that adult's relationships are similar to the mental models (Collins \& Read, 1990; Nelligan, Rholes, \& Simpson, 1992). In other researches attachment styles are related to the four attachment patterns (Brennan, Shaver, \& Tobey, 1991).

Adult attachment patterns were also applied to investigate the love relationship of adults (Fraley \& Shaver, 2000). Researchers concluded that the experiences of isolation, rejection and loss of caregiver in the childhood will later lead towards maladaptive behaviors in the adulthood like fear of love relationships (Hazan \& Shaver, 1987; Rubenstein \& Shaver, 1982; Weiss, 1973). Researchers observed parent-child relationship and love relationship of adults and concluded that both differ person to person in the same aspects. These individual differences exist on the basis of the anticipation of adult's love experience and their childhood memories of attachment with caregiver (Fraley \& Shaver, 2000). Hazan and shaver (1987) used the Ainsworth's three 
attachment patterns to investigate the nature of adult's love pattern.

Attachment style model: a pattern of adult attachment - John Bowlby introduced two images of adult attachment one is the self-image and the second is the others image and have been collected to portray attachment style of adults. Adult's view of self and others that is positive and negative have been collected with four types of adult's attachment style that are secure, preoccupied, fearful and dismissive (Bartholomew \& Horowitz, 1991). Unit one represents secure attachment style. In this unit, adult views himself as positive and valued person and others also as positive reactive, and approachable. This style enhances approval of both oneself and significant others. Secure attachment style is associated with high confidence level and self-esteem (Barrett \& Pietromonaco, 2000).

Unit two corresponds to preoccupied approach. Adult sees others as constructive, positive, and helpful and oneself as negative, pessimistic, unhelpful and unconstructive. Adult is welcomed and accepted by significant others and struggles to accept oneself. Unit three signifies fearful approach. Adult perceives both oneself and significant others as pessimistic, negative and distrustful. Adult stay away from interacting with others people and defend oneself from others. Unit four indicates dismissing pattern. Adult perceives oneself as optimistic and others as pessimistic. Adult signifies value and approval of oneself as well as indicates unconstructive and unhelpful outlook towards caregivers.

\subsection{Health}

Good health means to have complete physical, mental and emotional well-being. Food is an important component in maintaining the good health. Health can be of any type for example individual who can freely interact with people in the surrounding is said to have good social health. If the individual has grown up appropriately without any kind of delaying in the growth, perform better in all activities and day tasks has good mental health. If the individual has full control over himself and he does not let the events be imposed onto them and they can cope with the difficult situation easily has good emotional health. If the person feels himself free of all types of diseases has good physical health. Individual who feels himself free of stress, anxiety or if he can easily come out of the difficult situation has good psychological health.

Advantages of good health - Advantages of having good health are that the individual can perform better on all kind of tasks and can easily perform activities of daily life without experiencing pain, injury. The escape from these types of negative experiences lead person to have fruitful life as well as having the highest goal to be achieved in life. Individual with good health also have better sleep and more ability to accurately perform next day tasks. Good health is important for all ages and in all occupations.

Importance of research on health issues - Researchers stressed on the importance of health by saying that this phenomenon should be investigated thoroughly in order to maintain good health of public. Through conducting researches on the issue of health, individuals have the opportunities to experience therapies and examination through the tests as well as they get awareness about the precautions, signs, symptoms and treatment about the disease. So the researches on the health issues are very beneficial for the society (Gostin, Levit, \& Nass, 2009).

Nutrition and health issues - Inadequate nutrition has deleterious effects on health. Deaths of newborn babies are increasing in the countries where health issues are not taken under consideration. Consumption of nutritious food has health benefits like consuming fruits and vegetables have more advantages on health such as protection from terminal illnesses that is cancer or heart disease but consuming junk foods have disadvantages on health because people who consume fast food and deep-fried food are at higher risk of getting heart disease (Mascarenhas \& Mathers, 2009). Obesity is considered the most harmful in maintaining good health. A survey was conducted about obesity by World Health Organization (WHO). It was concluded that number of obese people was very high in the people with the ages of 20 and above. This ratio was found out in 2008 by WHO (World Health Organization). A few researches have been conducted on the phenomenon that people who skip 
their food affects their body weight. People who skip their first meal are at higher risk of getting overweight (Adams \& Morgan, 1998). Survey was conducted to check the obesity in older people and it was concluded that people who consume food in a large quantity are more obese than those who consume food in small quantity than they desire (Braun, Fabry, Fodor, Heji, \& Zvolankova, 1994). Life style is another threat to good health. People who live luxurious life style are more vulnerable to be diagnosed with obesity, cardiovascular disease and sugar imbalance (Fabray \& Tepperman, 1970).

There are a number of factors that affects health but nutritious factor is the most important. Inadequate consumption of fiber supplements like consumption of fruits, vegetables, grains like bread and rice and nuts increase the risk of cancer, cardiovascular disease and diabetes in people (Burkitt, Painter, \& Walker, 1972). As the number of fiber supplement increases the number of diseases decreases. People who consume more fat as well as more fiber are also at lower risk of cancer (Burkitt, 1984). Studying the health issues is helpful to alert people and be cautious about their food choices. Companies that provide packed food should keep in mind that food they are providing to the people is prepared on hygienic principles. (Labuza \& Lavine, 1990).

Relationship between psychological, emotional and mental health - It is generally said that health is the mental, emotional and psychological fitness. Clare and Shepherd (1981) stated that more than $20 \%$ of normal public experience emotional problems in daily life. Researchers concluded that emotional problems cause people to develop psychological disturbances like depression, anxiety and stress among the people of all ages. It was observed that individuals experience delayed growth and difficulties in academic activities as well as problem in health issues which may affect student's educational tasks and this inability to perform academic tasks accurately results in extra burden on students and make them mentally dissatisfied (Chan, Ho, \& Zaid, 2007; Lekhraj, Nadarajan, \& Sherina, 2003). This mental dissatisfaction leads individual to show maladaptive behaviors such as suicide and drugs addiction (Dahlin, Joneborg, \& Runeson, 2005).

In order to avoid all these issues, one should have good mental and emotional health. Giugliano (2004) stated that healthy individual is one who is mentally developed, easily establish social relationships, active and attentive in daily life because switch from childhood to adolescents, and then adolescents to adulthood and then older age is the toughest phase of life and many people find it difficult to adapt this change. Switch from one age group into two is the crucial time for individuals to set their eating habits because with increasing the age person's body needs more utilization of energy (Colic, Lukesic, \& Satalic, 2003). The person who can easily adjust with this evolution is thought to be a healthy person. Researches should be conducted on the issues related to health in order to investigate the risk factors that become obstacles in maintaining good health, then proper prevention, precautions and treatment should be planned to minimize the risk of psychological disturbances (Zulkefly, 2010).

Climate change affects health - In today's life there are a number of factors that cause mental disturbance among people so there is strong need to promote well-being (Herrman, Moodie, \& Saxena, 2005; Lopez \& Murray, 1996). As the atmosphere is changing rapidly, this change also has some effects on health (Campbell-Landrum et al., 2003). Researchers Blashki, Burke, Fritze, and Wiseman (2008) Stressed on the importance of the effect of atmosphere change on individual's well-being and they describes three factors that cause mental disturbance with changing atmosphere. One factor is that people living in the societies where daily hassles are most common are at higher risk of suffering from mental, psychological and social disturbances. Second reason is that atmosphere change is itself a big threat in maintaining good health. People suffer from throat infections, cough, fever and other health issues when the weather changes. Third is that, as the atmosphere is changing on the universal level is another risk of psychological distress. This may results in natural disaster like earthquakes, floods and tsunami.

These natural disasters directly affect individual's health and causes psychological disorder such as Post traumatic stress disorder (PTSD) (Few, 2007; Halpern \& Tramontin, 2007; Mayers, 1994). During the past 10 years, natural disaster management cells have become very active in predicting the upcoming disasters and 
Government is taking essential steps but there is a strong need to involve psychologists to recover people from the flashbacks of disaster to enhance mental health of the people who become victimized (Rao, 2006). Victims of the natural disasters suffer from many psychological disturbances which may inversely affect their physical health like individual he suffers from physical injury may also suffer from somatic disorder, those who lose their family members become drugs addict and experience stress, anxiety and depression (Silove \& Steel, 2006). Comparatively children are at higher risk of having psychological disturbances than adolescents or adults (Chen et al., 2003).

Socioeconomic factors that may affect health - Poverty is increasing day by day that expenditures are too high and income is very low is another issue that may affect health. In today's life, a large number of population is jobless and these jobless people cannot fulfill their basic needs necessary to live a healthy life. This may create lack of confidence, sense of worthlessness and ultimately person cannot make social contacts (Araya, DeLima, Ludermir, Patel, \& Todd, 1990; Price \& Shields, 2001).

Domestic violence - This is another major cause of mental disturbance. This leaves negative impact on the children because those children who experience violence like quarrel between parents are at higher risk of developing maladaptive personalities and exhibit antisocial behaviors. Violence leads to psychological disturbance like stress, anxiety and depression and affect person's well-being (WHO, 2002).

\subsection{Significance of the Study}

The study is important because it explores the breakfast as the factor that affects university student's health. The study is appealing to the students who skip breakfast as the fashion icon because they are unaware about the disadvantages of skipping breakfast. The study is helpful for the parents who let their child leave home with empty stomach because they may have lack of awareness about advantages of taking breakfast. The study addresses to the teachers and motivate them to deliver the lectures and conduct seminars in schools, colleges and universities about the importance and benefits of breakfast and aware them about the disadvantages of the skipping breakfast. This study helps the nutritionists so that they can easily differentiate healthy and unhealthy breakfast choices and make people realize about the disadvantages of unhealthy breakfast rich in caffeine and high sugar levels and benefits of healthy breakfast rich in vitamins and proteins. This study supports the researchers who want to conduct their researches on this phenomenon. Study explores the attachment patterns of university students. This study identifies that which attachment style adults have. The study is unique in its nature to explore the relationship between attachment style and health and it also establish the associations between breakfast taking habit and its effect on the health of university students.

Bandelow et al. (2005) in Germany conducted the research to observe that whether those individuals who think that they are protected can easily encounter difficult situations or not and also to explore that whether safety affects their individuality. The researcher selected 59 participants 43 were male and 16 were female participants. Results showed that 33\% individuals consider themselves as protected 35\% males (31\%) and females $(31 \%)$. But the ratio for unprotected was high as they were $67 \%$. Females were more concerned about their safety as their ratio (69\%) was higher than the males $(65 \%)$.

Abed, Abudayya, Holmboe-Ottesen, and Shi (2011) conducted study to establish relationship of food and academic activities. Researchers selected 932 students for the study. Students who consumed more vegetable and also consumed more fruits had good health and they performed better academic tasks as compared to those who did not consume these foods. A study was conducted by Chaplin and Smith (2011) in London with two aims. First was to investigate the relationship of taking the morning meal with the frequency of accidents, effect of first meal on performance and to check the effect of skipping morning meal and its effects on cognition. Second was to explore the effect of snacking on well-being. Researchers selected 800 nurses. It was seen that taking the morning meal decreased tension, enhance performance, and improve cognition.

Researches proved that attachment styles can predict behavior. This phenomenon was studied by the 
researcher Caspers, Spinks, Troutman, and Yucuis (2006) in United States of America (USA). Researchers selected 208 participants. Objective of the study was to explore the way in which respondent adjust with difficult situation. Participants were divided into two groups those who had safety issues and those who think themselves as protected. It was discovered that those participants who were more addicted had no desire to deal with their issues. But protected participants were not highly addicted.

Researcher Bobbert et al. (2012) in Germany conducted study. Researcher selected 44 obese participants 40 were females and 4 were males. Aim of the study was to investigate the prevalence of losing weight in those who were secure and compared them with those who were insecure. Those with insecure attachment style had less weight loss ability as compared to participants with secure attachment style. It was concluded that majority of participant $68 \%$ were secure. Fewer participants $32 \%$ were insecure. Out of the $32 \%$ only $14 \%$ were preoccupied and $18 \%$ were dismissive.

Andersson, Crondahl, Karlsson, and Sunnemark (2013) conducted a qualitative study in Roma, West Sweden people. People were experiencing illiteracy, isolation, poor well-being, favoritism in workplaces. Purpose was to explore people handle this situation and how they survive in those circumstances. It was concluded that people consider health as a state of fitness but threats to their well-being were being jobless, illiterate. But if the individual is educated, has a good job and social contacts all these are signs of maintaining good health. It was discovered that even they were facing favoritism in workplace overall they were satisfied with their life.

Ismail, Johari, Mahad, Moy, and Wan (2009) carried out research in Malaysia to explore the issues that cause people to omit morning meal. Researchers choose 2665 participants. Purpose was to discover the reasons of omitting morning meal. Ethnic background, life style, age, academic field, the night meal were major factors that make difference between children's breakfast habit. On the basis of age, it was discovered that as individual grow up the habit of omitting first meal decreases. On the ethnic basis, Chinese took regular took their morning meal when compared with other races like Malaysia and India. Another factor is the place where student lives. Students who live in their home were habitual to have their first meal as compared to those who live in hostels. It was seen that students who were studying science subjects were more aware about taking breakfast than those studying Arts subjects. Omitting night meal causes people to omit the first meal was another finding.

Green et al. (2002) carried out research to explore the effect of morning meal program in school on the student's dietary habits and tests scores in schools. A sample of 97 participants was taken as sample. It was concluded that $33 \%$ students were having poor diet and get poor grades, drowsiness and absenteeism. When these children participated in morning meal had good performance and they had better concentration when compared with those students who had appropriate dietary plan. In the end it was proved that morning meal offered by school was beneficent for children.

In Hyderabad (India), researchers Balakishna, Fernandez, Gajre, and Vazir (2008) carried out study to explore the effect of first meal on student's ability to remember something, awareness of surroundings, diet habits and their performance in school tests. They selected 379 participants for the study from sixth, seventh and eighth classes. The ages of students were 11-13 years. Researcher made two groups one who take daily take morning meal and the other group is that who skip their morning meal. Results showed that the group who took morning meal had good marks comparatively those who skipped their morning meal. Students who have their first meal daily were more aware of surroundings than those who don't. Overall, it was observed that taking morning meal daily improves children's activities.

Ciechanowski, Katon, Russo, and Walker (1996) in Washington conducted study to explore the attachment patterns. First half of the study was conducted in 1995 and remaining part was conducted in 1999. In the first phase 1225 participants were taken. In the second phase total of 1119 female participants was available. Participants who were worried and anxious were compared with those participants who thought that they were safe, and also they were protected from society. It was concluded that participants who had more safety issues 
Pervaiz, Z. \& Sohail, T.

about themselves showed more complaint than participants who believe they were safe.

\subsection{Objectives of the study}

$>$ To explore the associations between the types of breakfast and health of university students.

$>$ To explore the association between type of attachment and health of university students.

\subsection{Hypothesis}

It has been hypothesized that participants who take regular breakfast have better health than those who take irregular breakfast.

$>$ It has been hypothesized that participants who take irregular breakfast have better health when than those who take no breakfast.

It has been hypothesized that participants who take regular breakfast have better health than those who take no breakfast.

$>$ It has been hypothesized that participants who have improved self-model have good health than those who have high levels of others-model.

It has been hypothesized that participants who have high level in both models have improved health then those who have high level in others-model.

D It has been hypothesized that participants who have high levels in self model have improved health than those who have high levels in both-model.

\section{Method}

\subsection{Participants}

Researcher selected 200 participants from Lahore College for Women University; Lahore. Sample was selected from three social sciences department and three science departments. Participants from Psychology (24.5\%), Gender Studies (18\%), Economics (12\%), Biotechnology (15\%), Botany (16\%) and Zoology (14.5\%).Participants were selected from BS (hons) 4 year degree program. Age of the participants was between 17-22 years.

\subsection{Inclusion and Exclusion Criteria}

University students between the ages of 17 to 22 year and enrolled in four years BS program were included in the sample. University students fewer than 18 and above 22 were excluded from the study. The study did not include participants from Ms or Phd. Program.

\subsection{Sampling}

Purposive sampling technique was used in the study.

\subsection{Research Design}

Correlation design was used in the present study. The purpose of using the design was to explore the associations between the variables that were being studied. Whether breakfast was related to good health of the participants and if the participant's attachment pattern was related to the maintenance of good health? The study included three variables. One is the dependent variable and other two are independent variables. Two 
independent variables were breakfast and attachment styles. The study had one dependent variable that is general health.

Breakfast had three types. First group comprised of those participants taking breakfast regularly. Second group comprised of those participants taking breakfast irregularly. Third group comprised of those participants who skipped breakfast. Attachment styles were categorized in three groups. First group was comprised of participants with self-model. Participants who have positive feelings about oneself and negative feelings of others were included in the group. Second group comprised of those participants who had negative feelings about self and positive feeling about others. These participants were included in others-model. Third category was comprised of those participants who had the characteristics of above two models.

\subsection{Instruments}

Following instruments were used in the study. Demographic sheet was filled out by the participants to collect information about their demographic variables. Informed consent was signed by the participants to show their willingness to participate in the study and they were assured that their information was kept confidential.

Adult nutrition and performance questionnaire - This instrument was developed by Ashiq (2010). The scale has 8 questions. The first part of the scale investigates the breakfast habits of the university students whether they take regular, irregular or no breakfast at all. The second and third parts measure types of breakfast and lunch respectively the university students take. Fourth question measures frequency of fast food consumed. Fifth and sixth measure the behavioral and academic complaints seventh measures sleep hour and eight discovers health complaints.

General health questionnaire - This questionnaire (GHQ) was developed by Goldberg and Williams. Study used translated version of GHQ. It was downloaded from the website titled as Work and Health (2007). This questionnaire has 12 items and using 4 point scoring format ranging from 0 to 3 and the total score for the 12 items is 36 .

Relationship questionnaire - This questionnaire was developed by Bartholomew (1991). This questionnaire is comprised of four paragraphs each measuring a different attachment style. The first statement measures secure attachment style, second measures fearful, third statement assess preoccupied and the last determines dismissing.

\subsection{Procedure}

The sample of 200 was selected from Lahore College for Women University, Lahore. Permission was taken from the institution to collect data. Director of student's affair signed the letter and allow the researcher to take the sample. Selected participants were given the necessary instruction about the project. A booklet of five scales was administered on the participants. Participants were assured that all their information will be kept confidential, will be used only for academic purposes and will not be leaked out. Informed consent was given to the participants and asked them to sign the consent form and showed that they agreed to participate in the research. Demographic sheet was filled out by the participants. This sheet represented their familial information and also ensured the inclusion and exclusion criteria. Adult nutrition and performance questionnaire was administered on the participants. Participants were very excited while filling the form as it was related to their food habits. Relationship questionnaire and general health questionnaire were also given the participants to fill. Participants cooperated throughout the data collection process. Participants were given chocolates, biscuits and juices as a refreshment to participate in the project.

\section{Results}

The current study was conducted on female university students. Total number of the participants selected for the study was 200. Researcher investigated the association between habits of the morning meal and the food that 
Pervaiz, Z. \& Sohail, T.

is consumed. Another hypothesis was to distinguish the well-being of university students categorized in three models.

\section{Table 1}

Cross Tables of breakfast habits and health problems

\begin{tabular}{|c|c|c|c|c|c|c|}
\hline \multirow[b]{2}{*}{ Health problem } & \multicolumn{3}{|c|}{ Breakfast groups } & \multirow[b]{2}{*}{$X^{2}$} & \multirow[b]{2}{*}{$d f$} & \multirow[b]{2}{*}{$p$} \\
\hline & Regular breakfast & Irregular breakfast & No breakfast & & & \\
\hline Yes & $33 \%(0.3)$ & $12 \%(-2.1)$ & $20 \%(1.8)$ & 5.1 & 2 & $0.05^{*}$ \\
\hline No & $65 \%(-.3)$ & $44 \%(2.1)$ & $26 \%(-1.8)$ & & & \\
\hline
\end{tabular}

Note. ${ }^{*} \mathrm{p}=0.05, \mathrm{df}=2$

The above table explored the link between the university student's health and their breakfast pattern. It was discovered that the university students who daily have food showed no issues about their health (65\%) but a less number of students had some problems (33\%). The second group of those university students who randomly have breakfast had no issues related to their health (44\%) when they were compared with those who had some problems (12\%). The last group comprised of those who had no food (26\%) also had no issues of health. University students (20\%) having no food also had issues. it was explored that well-being of the university students who daily had their first meal was significantly different, $X^{2}(2, N=200)=5.1, p=0.05$.

\section{Table 2}

Analysis of variance between models and health

\begin{tabular}{lccccr}
\hline \multicolumn{1}{c}{ Health } & $D f$ & $S S$ & $M S$ & $F$ & $P$ \\
\hline Between-group & 2 & 135.46 & 67.73 & 2.45 & 0.08 \\
Within-group & 197 & 5440.09 & 27.61 & & \\
Total & 199 & 5575.55 & & & \\
\hline
\end{tabular}

Note. $p>0.05$, df $1=2, \mathrm{df} 2=197$

The table is showing differences of health between three models. One group is comprised of those people who fall in the category of self-model. The second group has the participants with others model. The last group includes of those university students who have both models. It was concluded that the number of university students $(\mathrm{n}=45)$ in the self-model was lower among the three but health outcomes was higher $(M=13.96, S D=$ 5.48) revealed that university students in this group has better health. The university students with others model has less university students $(\mathrm{n}=64)$. The general health of those students was also poor $(M=11.80, S D=4.90)$. The last category has the largest number of university students $(n=91)$. The health of the university students is lower $(\mathrm{M}=13.19, \mathrm{SD}=5.37)$ when compared with self-model university students. The results were not significant $(\mathrm{ns}), F(2,197)=2.45, p=0.08$.

\section{Discussion}

The current study was focusing on university student's health, their attachment pattern and the type of food. Targeted population was female university students. Researcher selected 200 university students. The study was conducted with the purpose to explore the differential patterns associated with variables health, attachment and breakfast habits of the university students. Study had one dependent variable that was the health of university students. One independent variable was attachment patterns. Other variable was breakfast habit. Breakfast habit was categorized in three groups. One group comprised of university students who daily had their breakfast. Second group had their meal randomly. Last group comprised of university student who omitted their meal. All hypotheses with exception of one in the study were proved.

Hypothesis that university students who daily had their first meal have better health from those who had irregularity or who omitted their breakfast to check the above hypothesis three groups were formulated. Health problems were also categorized in to two groups. One group had health issues. Second group had no health issues. Chi square was used to investigate the associations between well-being and breakfast habits of the 
university students. First relationship was explored between those university students (65\%) who daily had their breakfast and they also had no health issues. But another group of those university students (33\%) who had regular breakfast also exhibited health issues. This was the largest group having good well-being. It was observed that large number of university students daily had their breakfast. The second leading group was comprised of those university students who randomly had their breakfast. This group also showed good well-being (44\%). Some university students (12\%) despite having irregular food had poor well-being. Last group comprised of those students who omitted their breakfast. This group had poor well-being (20\%) and university student $(26 \%)$ who had good well-being. It was concluded that the university student who daily had their breakfast and who randomly had their breakfast both had some health issues like vomiting after having heavy breakfast. Minimum difference of health had been found between these two groups. But the last group who skipped first meal generally had poor well-being comparatively other two groups. This difference between the health issues and breakfast habit had been proved by the previous researches.

The findings of this hypothesis were similar to the literature. In Hyderabad (India), researchers Balakishna et al., (2008) focused on the significance of having healthy food in the morning to perform accurately throughout the day. But the current study was conducted in Pakistan. The reason that health outcomes of two breakfast groups were different may be that, study was conducted on female adults; some people are not habitual to breakfast from their childhood. Literature says that the tendency to have or to skip breakfast transfers from individual's childhood to the adulthood. University students who have irregular breakfast or no breakfast at all; their habit to skip breakfast has shifted from their childhood and now their stomach become used to skipping breakfast.

Another aim was to distinguish the well-being among models of the university students. Study failed to prove the hypothesis. Difference was not proved between well-being and attachment of university students. There were three classes of the university students depending on their attachment pattern. One class comprised of the university students was categorized as self-model. Second class of university student was categorized as others model and the last class of comprised of those university student having both models. Former studies had been conducted on the clinical population. But the current study was conducted on the normal population. In the former studies, researcher studied the issues experienced by those individuals who poor well-being. They were having some illness. Unprotected individuals experience more tensions, worries and then those who are secure. Individuals supported by their families and friends and have good relationship with others can easily encounter the difficult situations (Bandelow et al., 2005). In the study Bandelow et al., (2005) explored insecurity among addicts and concluded that insecure individuals had inability to encounter their well-being issues. Their assumption was proved. Above researchers focused on those individuals who had distress. Security decreased the risk of addiction. Bobbert et al (2012) stated that secure individuals easily participated in the campaign aimed to motivate the overweight people to lose weight. Borhani (2013) discovered that the individuals who were unprotected and threatened by society had maladaptive attitude. It was concluded that insecurity leads towards the addiction.

The above mentioned studies were conducted on those individuals having some health issues. The present study was conducted on female university students. Students had no major issues or no major disease that may be the reason for the slightly insignificance. Another factor may be that the questionnaire used for the university students. Questionnaire was actually used by practitioner. They usually use that tool for diagnosing psychological issues among clinical population. But in this study tool was used on normal population. So no major issues were explored in the university students. It was observed that different attachment pattern had no effect on the university student's well-being. Jackson (2007) stated that the tool was mostly administered by professionals. Its administration in academic field often does not provide the accurate information. More work can be done in Pakistan on attachment patterns.

The main finding of the study was the association between the breakfast and its outcomes on the university student's health. It was concluded that consuming the morning meal is related to the good wellbeing of the 
Pervaiz, Z. \& Sohail, T.

students. This finding was similar to the literature and hypothesis was accepted.

Another aspect about the university student's well-being and their attachment pattern was studied. It was concluded that the university student's attachment pattern had no effect on their well-being. This phenomenon was slightly insignificant.

\subsection{Strengths of the study}

The study is advantageous as it aware about the advantages of having breakfast.

The study unique in its nature that it was being conducted to find the association between health and attachment styles in normal population rather than clinical population.

\subsection{Limitations of the study}

Sample cannot be generalized to population.

Sample was selected from one institution of Lahore.

\subsection{Recommendations}

The current study was conducted on normal population but future researchers can conduct it on clinical population to find association between health and attachment styles. Research on the findings of breakfast and health relationship can be conducted on large scale.

\section{References:}

Abed, Y., Abudayya, A., Holmboe-Ottesen, G., \& Shi, Z. (2011). Diet nutritional status and school performance among adolescents in Gaza strip. Eastern Mediterranean Health Journal, 17(3), 218-225.

Abrahamsson, L., Fletcher, R., Jartelius, M., \& Wyon, D. (1997). An experimental study of the effects of energy intake at breakfast on the test performance of 10 year-old children in school. International Journal of Food Science and Nutrition, 48(1), 5-12. http://dx.doi.org/10.3109/09637489709006958

Adams, C., \& Morgan, K. (1981). Periodicity of eating: Implications for human food consumption. Nutrition Research, 1, 525-550. http://dx.doi.org/10.1016/S0271-5317(81)80056-5

Ahn, H. M., \& Bartfeld, J. S. (2011). The School Breakfast Program strengthens household food security among low-income households with elementary school children. Journal of Nutrition, 141(3), 470-475. http://dx.doi.org/10.3945/jn.110.130823

Ainsworth, M., \& Bowlby, J. (1991). An ethological approach to personality development. American Psychologist, 46, 331-341. http://dx.doi.org/10.1037/0003-066X.46.4.333

Akivis, A., Vaisman, N., Vakil, E., \& Vost, H. (1996). Effects of breakfast timing on the cognitive functions of elementary school students. Archives of Pediatric and Adolescent Medicine, 150, 1089-1092. http://dx.doi.org/10.1001/archpedi.1996.02170350091016

Alaimo, K., Briefel, R. R., Frongillo, E. A., \& Olson, C. M. (1998). Food insufficiency exist in U.S results from the third national health and nutrition examination survey. American Journal of Public Health, 88(3), 419-426. http://dx.doi.org/10.2105/AJPH.88.3.419

Alaimo, K., Frongillo, E. A., \& Olson, C. M. (2001a). Food insufficiency and American school-aged children's cognitive, academic and psychosocial development. Pediatrics 108(1), 44-53.

Alaimo, K., Frongillo, E. A., \& Olson, C. M. (2001b). Low family income and food insufficiency in relation to overweight in US children: Is there a paradox? Arch Pediatric Adolescence Medicine, 155(10), 1161-1167. http://dx.doi.org/10.1001/archpedi.155.10.1161

Allen, J. P., Beirne-Kelly, H. O., Kilmer, S. L., Kuperminc, G. P., Land, D. J., McElhaney, K. B., \& Moore, C. W. (2003). A secure base in adolescence: Markers of attachment security in the mother adolescent 
Breakfast, attachment styles and health of female university students

relationship. Child Development, 74(1), 292-307. http://dx.doi.org/10.1111/1467-8624.t01-1-00536

Allen, J. P., Kuperminc, G. P., Land, D. J., \& Moore, C. M. (1997). Developmental approaches to understanding adolescent deviance. In D. Cicchetti, J. Burak, J. Weisz, \& S. Luthar (Eds.), Developmental Psychopathology: Perspectives on Adjustment, Risk, and Disorder (pp. 548-567). New York: Cambridge University Press.

Almeida, D. M., Barker, E. T., \& Galambos, N. L. (2003). Parents do matter: Trajectories of change in externalizing and internalizing problems in early adolescence. Child Development, 74, 578-594. http://dx.doi.org/10.1111/1467-8624.7402017

Andersson, A., Crondahl, K., Karlsson, L. E., \& Sunnemark, F. (2013). The meaning of health well-being quality of life, perceived by Roma people in West Swedan. Societies, 3, 243-260. http://dx.doi.org/10.3390/soc3020243

Araya, R., Delima, M., Ludermir, A., Patel, V., \& Todd C. (1990). Women poverty and common mental disorders in four restructuring societies. Social Science and Medicine, 11(49), 1461-1471.

Ashiq, U. (2010). Breakfast habits and their effects on children's performance (Unpublished master's thesis). Lahore College for Women University, Lahore, Pakistan.

Balakrishna, N., Fernandez, S., Gajre, N., \& Vazir, S. (2008). Breakfast eating habit and its influence on attention-concentration, immediate memory and school achievement. Indian Pediatrics, 45, 824-828.

Barrett, F. L., \& Pietromonaco, P. R. (1997). Working models of attachment and daily social Interactions. Journal of Personality and Social Psychology, 73, 1409-1423. http://dx.doi.org/10.1037/0022-3514.73.6.1409

Barrett, L., \& Pietromonaco, P. (2000). The internal working model concept: What do we really know about the self in relation to others? Review of General Psychology, 4, 155-175. http://dx.doi.org/10.1037/1089-2680.4.2.155

Bartholomew, K. (1991). The relationships questionnaire. Retrieved from http://www.fetzer.org/sites/default/files/images/stories/pdf/selfmeasures/Attachment-RelationshipsQuest ionnaire.pdf

Bartholomew, K., \& Griffin, D. (1994). Models of self and others fundamental dimensions underlying measures of adult attachment. Journal of Personality and Social Psychology, 67(3), 430-445. http://dx.doi.org/10.1037/0022-3514.67.3.430

Bartholomew, K., \& Horowitz, L. (1991). Attachment styles among young adults: A test of four category model. Journal of Personality and Social Psychology, 61, 226-244. http://dx.doi.org/10.1037/0022-3514.61.2.226

Berghaus, B. (2011). A new look at attachment theory and adult attachment behavior. Behaviorology Today, 14(2), 3-10.

Berman, W., \& Sperling M. (Eds.). (1994). Attachment in adults clinical and developmental Perspectives. New York: Guilford press.

Bhattacharya, J., Currie, J., \& Haider, S. J. (2006). Breakfast of champions? The schoolbreakfast program and the nutrition of children and families. Journal of Human Resources, 41(3), 445-466.

Blashki, G., Burke, S., Fritze, J., \& Wiseman, J. (2008). Hope, despair and transformation: Climate change and the promotion of mental health and well-being. International Journal of Mental Health Systems, 2(13).

Bobbert, T., Deter, H., Kallenbach, B., Kiesewetter, S., Kopp, W., Kopsel, A.,...... Stroux A. (2012). Attachment style contributes to the outcome of a multimodal lifestyle intervention. Biopsychosoical Medicine, 6(3).

Borhani, Y. (2013). Substance abuse and insecure attachment style: A relational study. A Journal of Transdisciplinary Writing and Research form Claremont Graduate University, 2(1).

Braun, T., Fabry, P., Fodor, J., Heji, Z., \& Zvolankova, K. (1994). The frequency of meals: its relation to overweight, hypercholesterolemia and decreased glucose-tolerance. Lancet, 1, 614-615.

Brennan, K., Shaver, P., \& Tobey, A. (1991). Attachment styles gender and parental problem drinking. Journal of Social and Personal Relationships, 8, 451-466. http://dx.doi.org/10.1177/026540759184001

Bretherton, I. (1992). The origin of attachment theory. John Bowlby and Mary Ainsworth. Developmental Psychology, 28(5), 759-775. http://dx.doi.org/10.1037/0012-1649.28.5.759 
Pervaiz, Z. \& Sohail, T.

Bretherton, I. (2003). Mary Ainsworth. Insightful observer and courageous theoretician. In A. Kimbel \& M. Wertheimer (Eds.). Portraits of pioneer in psychology (pp. 317-331). Hillsdale, New Jersey: Lawrence Erlbaum Associates.

Brooks-Gunn, J., \& Paikoff, R. L. (1991). Do parent-child relationships change during puberty? Psychology Bulletin, 110, 47-66. http://dx.doi.org/10.1037/0033-2909.110.1.47

Bryant, C. A., Courtney, A., McDermott, R. J., \& Morris, C. T. (2010). Grab N go breakfast at school observation from a pilot program. Journal of Nutrition Education and Behavior, 42(3), 208-209. http://dx.doi.org/10.1016/j.jneb.2009.10.003

Burkitt, D. (1984). Etiology and prevention of colorectal cancer. Hospital Practice, 19(2), 67-77.

Burkitt, D., Painter, N., \& Walker, A. (1972). Effect of dietary fiber on stools and transit time and its role in the causation of disease. Lancet, 2, 1408-1412. http://dx.doi.org/10.1016/S0140-6736(72)92974-1

Campbell-Lendrum, D., Corvalan, C., Ebi, K., Githeko, A., McMichael, A., Scheraga, J., \& Woodward, A. (Eds.). (2003). Climate change and human health: risks and responses. Geneva: World Health Organization.

Carnelly, K., Jaffe, K., \& Pietromonaco, P. (1994). Depression working models of others and relationship functioning. Journal of Personality and Social Psychology, 66, 127-170. http://dx.doi.org/10.1037/0022-3514.66.1.127

Caspers, K. M., Spinks, R., Troutman, B., \& Yucuis, R. (2006). Attachment as an organizer of behavior: implications for substance abuse problems and willingness to seek treatment. Substance Abuse Treatment, Prevention and Policy, 1(32). http://dx.doi.org/10.1186/1747-597X-1-32

Chan, S., Ho, J., \& Zaid, Z. (2007). Emotional disorders among medical students in Malaysian private medical school. Singapore Medical Journal, 48(10), 895-899.

Chandler, A., Connolly, K., Grantham-McGregor, S. M., \& Walker, S. P. (1995). School breakfast improves verbal fluency in undernourished Jamaican children. Journal of Nutrition, 125(4), 894-900.

Chang, S., Grantham-McGregor, S., \& Walker, S., (1998). Evaluation of school feeding programs: Some Jamaican examples. American Journal of Nutrition, 67(4), 785-789.

Chaplin, K., \& Smith, A. P. (2011). Breakfasts and snacks: association with cognitive failure, minor injuries, accidents and stress. Nutrients, 3, 515-528. http://dx.doi.org/10.3390/nu3050515

Charnov, E. L., Estes, D., Gardner, W. E., Lamb, M. E., \& Thompson, R. A. (1985). Security of infantile attachment as assessed in the "strange situation": Its study and biological interpretation. In A. Thomas \& S. Chess (Eds.), Annual progress in child psychiatry and child development (pp. 53-114). New York: Brunner/Mazel.

Chen, C., Hu, W., Kuo, C., Tang, H., Tsay, C., \& Lin S. (2003). Prevalence of psychiatric disorders among bereaved survivors of a disastrous earthquake in Taiwan. Psychiatric Services, 54, 249-251.

Ciechanowski, P. S., Katon, W. J., Russo, J. E., \& Walker, E. A. (1996). Attachment theory: A model for health care utilization and somatization. Psychosomatic Medicine, 64, 660-667. http://dx.doi.org/10.1097/01.PSY.0000021948.90613.76

Clare, A., \& Shepherd, M. (1981). Psychiatric illness in general practice. Oxford: Medical Publications.

Clark, M. A., \& Fox, M. K. (2009). Nutritional quality of the diets of U.S. public school children and the role of the school meal programs. Journal of the American Dietetic Association, 109(2), 44-56. http://dx.doi.org/10.1016/j.jada.2008.10.060

Colic, B., Lukesic, Z., \& Satalic, Z. (2003). Nutritive values of meals dietary habits and nutritive status in Croatian university students according to gender. International Journal Food Science Nutrition, 54, 473-484. http://dx.doi.org/10.1080/09637480310001622332

Collins, N. L., Cooper, M. L., \& Shaver, P. R. (1998). Attachment styles, emotion regulation and adjustment in adolescence. Journal of Personality and Social Psychology, 74, 1380-1397. http://dx.doi.org/10.1037/0022-3514.74.5.1380

Collins, S., \& Read, J. (1990). Adult attachment, working models and relationship quality in dating couples. Journal of Personality and Social Psychology, 58, 644-663. http://dx.doi.org/10.1037/0022-3514.58.4.644

Cueto, S. (2001). Breakfast and dietary balance: The enkid study. Public Health Nutrition, 4(6A), 1429-1431. 
Breakfast, attachment styles and health of female university students

Cueto, S., Jacoby, E., \& Pollitt, E. (1998). Fasting and cognition in well-undernourished school children: a review of three experimental studies. American Journal of Clinical Nutrition, 17, 54-64.

Dahlin, M., Joneborg, N., \& Runeson, B. (2005). Stress and depression among medical students. A cross-sectional study. Medical Education, 39, 594-604. http://dx.doi.org/10.1111/j.1365-2929.2005.02176.x

Deci, E. L., Grolnick, W. S., \& Ryan, R. M. (1995). Autonomy, relatedness and the self: Their relation to development and psychopathology. In D. Cicchetti \& D. Cohen (Eds.), Developmental Psychopathology: Theory and Methods. Wiley Series on Personality Processes (Vol. 1, pp. 618-655). New York: John Wiley \& Sons.

Doyle, A. B., Ducharme, J., \& Markiewicz, D. (2002). Attachment security with mother and father: Associations with adolescents' reports of interpersonal behavior with parents and peers. Journal of Social and Personal Relationship, 19, 203-231. http://dx.doi.org/10.1177/0265407502192003

Emerson, P. F., \& Schaffer, H. R. (1964). The development of social attachments in infancy. Monographs of the Society for Research in Child Development, 29(94).

Fabray, P., \& Tepperman, J. (1970). Meal-frequency: possible factor in human pathology. American Journal of Clinical Nutrition, 23, 1059-1068.

Few, R. (2007). Health and climatic hazards: framing social research on vulnerability response and adaptation. Global Environmental Change, 17, 281-295. http://dx.doi.org/10.1016/j.gloenvcha.2006.11.001

Fraley, R., \& Shaver, P. (2000). Adult romantic relationship: theoretical developments emerging Controversies and unanswered questions. Review of General Psychology, 4(2), 132-154. http://dx.doi.org/10.1037/1089-2680.4.2.132

Giugliano, R. (2004). The systematic neglect of New York's young adults with mental illness. Psychiatric services, 55(4), 451-453. http://dx.doi.org/10.1176/appi.ps.55.4.451

Gleason, P., \& Suitor, C. (2001). Children's diets in the mid-1990s: dietary intake and its relationship with school meal participation (Report No. CN-01-CD1). United States Department of Agriculture.

Gostin, L., Levit, L., \& Nass, S. (2009). Health insurance portability and accountability act of 1996. Washington DC: The national academic press.

Grantham-McGregor, S., \& Simeon, D. T. (1989). Effects of missing breakfast on the cognitive function of school children of differing nutritional status. American Journal of Clinical Nutrition, 49, 646-53.

Green, H., Hall, S., Kleinman, R., Murphy, M., Pagano, M., Patton, K., \& Korzec, D. (2002). Diet breakfast and academic performance in children. Annals of Nutrition and Metabolism, 46(1), 24-30.

Greenfield, D., Leibel, R.L., \& Pollitt, E. (1981). Brief fasting, stress, and cognition in children. American Journal of Clinical Nutrition, 34, 1526-1533.

Hails, S., Helms, G., Pincock, C., Richardson, D., \& Wesnes, K. A. (2003). Breakfast reduces declines in attention and memory over the morning in school children. Appetite, 41(3), 329-331. http://dx.doi.org/10.1016/j.appet.2003.08.009

Halpern, J., \& Tramontim, M. (2007). Disaster mental health: theory and practice. Belmont CA: Thomson.

Hazan, C., \& Shaver, P. R. (1987). Romantic love conceptualizes as an attachment process. Journal of Personality and Social Psychology, 52(3), 511-524. http://dx.doi.org/10.1037/0022-3514.52.3.511

Hazan, C., \& Shaver, P. R. (1990). Love and work an attachment theoretical perspective. Journal of Personality and Social Psychology, 59(i2). http://dx.doi.org/10.1037/0022-3514.59.2.270

Hazan, C., \& Shaver, P. R. (1993). Adult romantic attachment: theory and evidence. In D. Perlmman \& W. Jones (Eds.), Advances in personal relationships (Vol.4, pp. 29-70). London: Jessica Kingsley.

Herrman, H., Moodie, R., \& Saxena, S. (Eds.). (2005). Promoting mental health concepts, emerging evidence practice. Geneva: World Health Organization.

Holland, R., \& Moretti, M. M. (2003). Navigating the journey of adolescence: Parental attachment and the self from a systemic perspective. In S. Johnson \& V. Whiffen (Eds.), Clinical Applications of Attachment Theory (pp. 41-56). New York: Guildford.

Ismail, Y., Johari, S., Mahad, R., Moy, F., \& Wan, W. (2009). Breakfast skipping and its associated factors among undergraduates in a public University in Kuala Lumpur. Malaysian Journal of Nutrition, 5(2), 165-174. 
Jackson, C. (2007). The general health questionnaire. Occupational Medicine, 57(79).

Jellinek, M. S., Kleinman, R. E., Little, M., Murphy, J. M., Pagano, M., Regal, K., \& Wehler, C. A. (1998). Hunger in children in the United States: Potential behavioral and emotional correlates. Pediatrics, 101(1).

Kane, S., Kleinman, R., Murphy, J. M., Nachmani, J., Pagano, M., \& Sperling, P. (1998). The Relationship of School Breakfast to Psychosocial and Academic Functioning: Cross-sectional and longitudinal observations in an inner-city sample. Archives of Pediatric and Adolescent Medicine, 152, 899-907. http://dx.doi.org/10.1001/archpedi.152.9.899

Kirkpatrick, L., \& Shaver, P. (1992). An attachment theoretical approach to romantic love and religious belief. Personality and Social Psychology Bulletin, 18, 266-275. http://dx.doi.org/10.1177/0146167292183002

Kobak, R. R., \& Sceery, A. (1988). Attachment in late adolescence: Working models, affect regulation, and representations of self and others. Child Development, 59,135-146. http://dx.doi.org/10.2307/1130395

Labuza, T., \& Lavine, A. (1990). Food systems: the relationship between health and food science technology. Environmental Health Perspectives, 86, 233-238. http://dx.doi.org/10.1289/ehp.9086233

Lamborn, S. D, \& Steinberg, L. (1993). Emotional autonomy redux: Revisiting Ryan and lynch. Child Development, 64, 483-499. http://dx.doi.org/10.2307/1131264

Lekhraj, M. Nadarajan, R. \& Sherina, K. (2003). Prevalence of emotional disorders among medical students in a Malaysian University. Asia Pacific Family Medicine, 2, 213-217. http://dx.doi.org/10.1111/j.1444-1683.2003.00089.x

Lessard, J. C., \& Moretti, M. M. (1998). Suicidal ideation in an adolescent clinical sample: Attachment patterns and clinical implications. Journal of Adolescence, 383-395. http://dx.doi.org/10.1006/jado.1998.0169

Lessard, J.C. (1994). The role of psychological distress and attachment in adolescent substance use (Unpublished master's thesis). Simon Fraser University, Vancouver, British Columbia.

Lopez, A., \& Murray, C. (Eds.). (1996). The global burden of disease. Cambridge: Harvard University Press.

Mascarenhas, M., \& Mathers, C. (2009). Global health risks mortality, and burden of disease attributable to selected major risks. Geneva: World Health Organization.

Mathew, R., \& Pollitt, E. (1998). Breakfast and cognition: an integrative summary. American Journal of Clinical Nutrition, 67(4), 804-813.

Mayers, D. (1994). Disaster response and recovery: A hand book for mental health professionals. Washington DC: Diane Publisher.

Mikulincer, M., \& Nachshon, O. (1991). Attachment styles and pattern of self-disclosure. Journal of Personality and Social Psychology, 61, 321-331. http://dx.doi.org/10.1037/0022-3514.61.2.321

Moretti, M. M., \& Peled, M. (2004). Adolescent parent attachment bonds that support healthy Attachment. Pediatric Child Health, 9(8), 551-555.

Morgan, K., Stampley, G., \& Zabik, M. (1986). The role of breakfast in diet adequacy of U.S adult population. Journal of American College of Nutrition, 5, 551-563. http://dx.doi.org/10.1080/07315724.1986.10720156

Murphy, J. M. (2007). Breakfast for learning: An updated review. Journal of Current Nutrition and Food Science, 3(1), 3-36. http://dx.doi.org/10.2174/1573401310703010003

Nelligan, J. S., Rholes, W. S., \& Simpson, J. A. (1992). Support seeking and support giving with in couples in an anxiety-provoking situation. Journal of Personality and Social Psychology, 62, 434-446. http://dx.doi.org/10.1037/0022-3514.62.3.434

Ozcelik, A. O., Ozdogan, Y., \& Surucuoglu. (2010). The breakfast habits of female university Students. Pakistan Journal of Nutrition, 9(9), 882-886. http://dx.doi.org/10.3923/pjn.2010.882.886

Pincus, A., Ray, W., \& Simonelli, L. (2004). Attachment models and their relationship with anxiety worry and depression . Counseling and Clinical Psychology Journal, 1(3), 107-118.

Pollitt, E. (1995). Does Breakfast Make a Difference in School? Journal of the American Dietetic Association, 95(10), 1134-1139. http://dx.doi.org/10.1016/S0002-8223(95)00306-1

Price, S. W., \& Shields, M. A. (2001). Exploring the economic and social determinants of psychological and psychosocial health. Journal of the Royal Statistical Society, 168(3), 513-538. 
Breakfast, attachment styles and health of female university students

Rao, K. (2006). Psychosocial support in disaster affected communities. International Review of Psychiatry, 18(6), 501-505. http://dx.doi.org/10.1080/09540260601038472

Rubenstein, C., \& Shaver, P. (1982). Childhood attachment experience and adult loneliness. In L, Wheeler (Ed.). Review of personality and social psychology (Vol. 1, pp. 42-73). Beverly Hills CA: Sage publications.

Segrin, C., \& Flora, J. (2005). Family Communications. Mahwah, New Jersey: Lawrence Erlbaum Associates.

Shaver, P., \& Tracy, J. (2001). Attachment style and adolescent sexuality. In P. Florsheim (Ed.). Adolescent romance and sexual behavior: Theory, research, and practical implications. Mahwah, New Jersey: Lawrence Erlbaum Associates.

Silove, D., \& Steel, Z. (2006). Understanding community psychosocial needs after disasters: Implications for mental health services. Journal of Postgraduate Medicine, 52, 121-125.

Simpson, J. (1990). The influence of attachment styles on romantic relationships. Journal of Personality Psychology and Social Psychology, 59, 971-980. http://dx.doi.org/10.1037/0022-3514.59.5.971

Sroufe, L.A., \& Waters, E. (1977). Attachment as an organizational construct. Child Development, 48, $1184-1199$. http://dx.doi.org/10.2307/1128475

Wedekind, D., Bandelow, B., Engel, K. R., Havemann-Reinecke, U., Heitmann, S., \& Huether, G. (2005). Attachment style, anxiety, coping and personality-styles in withdrawn alcohol addicted inpatients. Substance Abuse, Treatment, Prevention and Policy, 8(1). http://dx.doi.org/10.1186/1747-597X-8-1

Weiss R. (1973). Loneliness: The experience of social and emotional isolation. Cambridge Massachusetts: Massachusetts Institute of Technology Press.

Work and Health. (2007). General Health Questionnaire (pp 19-21). Retrieved from http://www.workhealth.org/UCI\%202007/practicum\%2008\%20GHQ\%202007.pdf

World Health Organization . (2002). World Report on Violence and Health. Geneva: World Health Organization.

Zabik, M. (1987). Impact of ready-to-eat cereal consumption on nutrient intake. Cereal Food World, 32(3), 234-239.

Zulkefly, N. (2010). Using the 12-iem general health questionnaire to assess the psychological health of Malaysian college students. Global Journal of Health Science, 2(1), 73-80. 
Pervaiz, Z. \& Sohail, T. 